\title{
THE EFFECT OF PSYCHOLOGICAL CAPITAL ON WORK ENGAGEMENT WITH JOB CRAFTING AS A MEDIATOR VARIABLE AMONG GENERATION Y EMPLOYEES
}

\author{
Andini Adelia Gustitia \\ Department of Industrial and Organizational Psychology, Faculty of Psychology, \\ University of Airlangga, Surabaya, Indonesia \\ E-mail: adelia.gustitia.andini-2017@psikologi.unair.ac.id
}

\begin{abstract}
This study aims to examine whether there is a psychological capital effect on work engagement with job crafting as a mediator variable in Generation $\mathrm{Y}$ employees. The definition of work engagement in this study refers to the theory revealed by Schaufeli, et al. (2002), psychological capital using the Luthans theory, et al. (2004), and job crafting using the theory of Tims, et al. (2011). The subjects in this study were 82 people with the criteria of individuals who were working and aged 20 to 36 years. The scale used in this study is the Utrecht Work Engagement Scales (UWES) which consists of 15 items, Job Crafting Scales (JCS) which consist of 18 items, and the PsyCap Questionnaire (PCS) which consists of 24 items. Data analysis use simple and multiple linear regression methods based on the mediation test analysis techniques of Baron and Kenny (1986). The results of the analysis show that job crafting mediates the influence of psychological capital on work engagement on Generation Y employees.
\end{abstract}

\section{KEY WORDS}

Job crafting, work engagement, generation $Y$ employees.

The workforce in an organization will always change and be dynamic as employees retire and are replaced by employees of the new generation (Ozcelik, 2015). In the company there are four generations, including Silent Generation or commonly known as Traditionalist where these people were born in 1925-1945, Baby Boomers born in 1946-1964, Generation X who were born in 1965-1981, and Generation Y or Millennials born in 1982-1999 (Schullery, 2013). In 2014, 36\% of Generation $Y$ has entered the workforce, and there is a possibility that in 2020 46\% of Generation Y will dominate the workforce (Park \& Gursoy, 2012). In this era, Indonesia is experiencing increasingly fierce competition to get generation $Y$ human resources because this generation prefers digital-based pilot businesses with attractive work cultures (Korporasi Bersaing Memikat Generasi Y, 2016). Characteristics of generation $Y$ are different from the older generation who prefer to settle on their current work (Browning \& Worman, 2008). There was a survey conducted by the University of California where $70 \%$ of generation $Y$ planned to change jobs after the economy improved, $80 \%$ stated that they wanted direct feedback compared to traditional performance appraisal, $43 \%$ felt very confident that they will find another job if they quit or lose the current job, and $65 \%$ stated that self-development is the most influential factor in their current job (Kratz, 2013). According to Park and Gursoy (2012), generation $Y$ has a tendency to two times larger than the generation $X$ to quit his job after one year of working. High turnover in a company shows a low commitment to the organization, and indirectly it shows low work engagement. Halbesleben and Wheeler (2008) reveal that employees feel not engaged to their job because they do not get the opportunity to invest their energy in work, have low identification and meaning in their work so they will choose to leave the company. But still, organization really need this generation $Y$ because they are considered the most intelligent, diligent, optimistic, confident, and is the homo sapiens that is most needed to face world challenges than other generations (Zemke et al., 2013).

Organization needs to pay attention on employee's work engagement because it is related to important business outcomes such as the willingness of employees to continue working in the company, productivity, profits, loyalty, and customer comfort. The more 
employees have a high sense of attachment with the company; the business income will also increase (Rachmawati, 2013). In work engagement, there is energy and focus that is attached to the employees which makes them able to give full potential to their work. It can also improve the quality of responsibility and motivation to concentrate exclusively on what they are doing (Leiter \& Bakker, 2010).

According to Vogt, et al (2016; Cenciotti, et al. 2017) in his research stated that there is a reciprocal relationship between work engagement, job crafting, and psychological capital. Psychological capital is a positive state of an individual characterized by self efficacy, optimism, hope and resilience. The four dimensions will direct individuals to be more attached to their work, such as working harder (vigor), feeling that work is meaningful and useful (dedication), and fully willing to focus on completing work (absorption) (Rostiana \& Lihardja, 2013). One of the predictors that make employee will engaged to their work is job crafting, where individuals have the initiative to make changes to their work environment related to job demands and job resources (Tims, et al., 2011). And according to research that conducted by Cenciotti, et al. (2017) states that job crafting can increase a person's psychological capital.

Based on the explanation above, this study uses job crafting as a mediator variable in connecting psychological capital with work engagement. This research was conducted to prove the relationship of the three variables. Based on the explanation above, a question arises, whether the effect of psychological capital on work engagement on generation $Y$ employees is mediated by job crafting.

\section{LITERATURE REVIEW}

Generation $Y$ or Millenials are people born in 1982-1999. When baby boomers retire, this generation begins to enter the world of work (Reder et al., 2010 in Marais, 2013). During their growth, generation $Y$ was heavily influenced by massive expansion of technology and mass media. Meirer and Crocker (2010) revealed that generation $Y$ is different from the older generation who depend on their work, individuals from generation $Y$ do not feel dependent and do not consider work as the most important thing in their lives.

Other than that, the characteristic of this generation is that they want to be respected and recognized by their workplace, they also always want to develop and learn. If they feel their work environment does not respect them, they will not hesitate to leave the organization (Hoole \& Bonnema, 2015). Lutungan, et.al., (2014) also did a research and stated that this generation have some characteristic such as: 1) result oriented; 2) frontal communication behaviour; and 3) pay attention to social influences and prioritize job satisfaction.

Work engagement is assumed to be the opposite of burnout. Burnout is defined as fatigue, cynicism, and something that decreases one's efficacy (Maslach \& Leiter, 1997, in Schaufeli \& Bakker, 2003). Employee who engages feel encouraged and effectively connected with his work, they also see themselves as someone who is able to cope with the demands of the job well (Schaufeli \& Bakker, 2003). Kahn (1990; Saks, 2006) defines attachment as someone's psychological presence when carrying out the role of the organization, which means that someone is really involved both physically, psychologically, emotionally, and cognitively when working. Rothbard (2001; Saks, 2006) stated that there are two critical things on engagement such as attention (availability of cognitive thinking and time to the roles carried out in the organization), and absorption (focus and sinking of someone in the role being carried out).

According to Schaufeli, et al. (2002), work engagement is defined as a positive state of mind, full involvement in work characterized by enthusiasm, dedication, and absorption of work. Employees who are engaged will feel compelled to strive towards challenging goals and desires success. Work engagement reflect the energy of employees brought to work, they not only feel excited but also feel enthusiastic about using their energy in their work (Leiter \& Bakker, 2010). Employees who engaged have desire to work hard, involve in the organization, and feel happy with their work (Taris, et al., 2010). 
Work engagement has three dimensions, dedication and absorption (Schaufeli \& Bakker, 2010). Vigor is characterized by high levels of energy and mental resilience while working, willingness to give effort on task, and persistent even though there is a difficulty. Dedication is characterized by full involvement in a job, having important feelings, enthusiasm, inspiration, pride, and feeling challenged. Absorption is characterized by full concentration and feeling happy when working, where employees will feel time flies and found it difficult to break away from work (Schaufeli \& Bakker, 2010).

Work engagement is positively associated with job resources goals, and can improve growth, learning and development (Schaufeli \& Salanova, 2007). Demerouti, et al. (2001; Schaufeli \& Bakker, 2004) did a research about JD-R theory (Job Demand-Resources) and state that job demands like working hours or time pressure can cause fatigue, meanwhile lack of job resources such as feedback, social support, participation in decision making will cause disobedience. Not only job demands and resources, psychological capital is also a factor that influences work engagement. Psychological capital is a employee's positive state that characterized by self efficacy, optimism, hope, and resilience (Luthans et al., 2007; Sweetman \& Luthans, 2010). The four psychological capital dimensions will produce and direct individuals to take useful actions to motivate someone to work harder (vigor), feel that their work is meaningful and (dedication), and fully willing to focus on completing their work (Rostiana \& Lihardja, 2013). Bakker, et al., (2012) conducted a study and revealed a predictor that also significantly affects the work engagement, named Job Crafting. According to Tims, et al. (2012), job crafting is defined as the self-initiated changes that employees make in their own job demands and job resources to attain and/or optimize their personal (work) goals. Employees who show job crafting behaviour will be more attached to their jobs, because they proactively try to align their work conditions with their needs and abilities (Tims, et al., 2012).

Wrzeniewski and Dutton coined the term job crafting in 2001, but actually the idea of job crafting was already mentioned over 20 years ago by Kulik, Oldham, and Hackman in 1987. The research shows that employees could redesign the jobs on their own initiative with or without the involvement of management (Tims, et al., 2011). In job crafting, individuals physically and cognitively change the task and relationship in the workplace (Wrzesniewski \& Dutton, 2001). The physical changes refer to the scope, shape, number of tasks, and relationships at work, while cognitive change refers to how a person changes perceptions about his work (Bakker et al., 2012).

According to Tims, et al. (2012), job crafting is defined as the self-initiated changes that employees make in their own job demands and job resources to attain and/or optimize their personal (work) goals. Berg and Dutton (2008, in Tims, et al., 2011) reveal that there is important point on job crafting where employees do not change the whole work, but they change certain aspects within specific task boundaries. For example, job crafting involved more autonomy which can encourage employees to feel more responsible for their performance, and consequently they will be more motivated to give effort to each task they do (Parker \& Ohly, 2008; Tims et al., 2011).

Tims, et al. (2012, in Siddiqi, 2015) states that job crafting is divided into four categories of dimensions, such as increasing structural job resources, decreasing hindering job demands, increasing social job resources, increasing challenging job demands. In the increasing structural job resources dimension, employees may strive to enhance the structural resources such as demanding variety in their resources, more autonomy, responsibility improving job know-how from their employers to attain self development and seeking more opportunity for their growth and advancement in order to improve the performance both at the employee or organizational levels. In the decreasing hindering job demands dimension employees may reduce the number of tasks by doing away with some of the tasks they feel both physically and psychologically uncomfortable with or they may consciously avoid engagements that make their overall job overwhelming. In the increasing social job resources, employees may seek guidance, opinions, ask for feedback from superiors, subordinates, or colleagues in order to improve their performance. In the increasing challenging job demands dimension, employees may attempt to broaden the 
scope of their job or mix and remix the tasks of the job to make it more challenging in order to maintain interest and avoid boredom in one's job.

In the development of research on Positive Organizational Behaviour (POB), there is a new concept formulated by Luthans et al. (2004), named positive psychological capital. Psychological capital can be defined as a positive state of a person that characterized by: self efficacy to try or do a challenging task, optimism about the success in the present and the future, perseverance in achieving goals and having a hope and resilient in the face of problems and continue to strive to achieve success (Luthans, Youssef, \& Avolio, 2007). Psychological capital has four dimensions, namely self efficacy, optimism, hope, and resiliency.

The first dimension is self efficacy, based on Bandura $(1986,1997)$ theory self efficacy can be defined as a person's belief in the ability that can encourage to be motivated and as an individual's way of acting in order to be successful in doing certain jobs (Stajkovic \& Luthans, 1998; Luthans, et al., 2007). The second dimension is Hope. Hope is a state of positive psychology that is based on mutual awareness between agencies or the power to achieve goals and path ways or planning in achieving goals. Snyder (1991) conducted a study that revealed that hope is a cognitive condition in which individuals are able to set and achieve a goal and target through means of self directed, energy, and perceptions of selfcontrol (Luthans, et al., 2007). The third dimension is Optimism. Optimism is defined as a model of thinking in which individuals attribute positive events into themselves, are permanent, and the cause is pervasive, and is a factor caused by certain situations. Individuals who are optimistic will feel involved in positive events that occur in a long time, seeing that the causes of positive or pleasant events are in the power and self-control of individuals (Seligman, 1998; Luthans, et al., 2007). The fourth dimension is resiliency which is defined as a collection of phenomena characterized by positive patterns of adaptation in a deteriorating context (Masten \& Reed, 2002; Luthans, et al., 2007). In psychological capital, resiliency is not only seen as an ability to rise again from adversity, but it is also a very positive thing in facing an event that is challenging and is an ability to exceed the normal limits and balance points of the individual (Avolio \& Luthans, 2006; Luthans, 2002; Youssef \& Luthans, 2005b; Luthans, et al., 2007).

\section{METHODS OF RESEARCH}

The subjects in this study were Generation $Y$ employees aged 20 to 36 years. Sampling in this study was non-probability techniques with accidental sampling method. The use of this sampling technique allows samples to be taken randomly, so the bias can occur. The number of samples in this study was 82 people with a percentage of $40 \%$ men, as many as 33 people and $59.8 \%$ women, as many as 49 people. Subjects on average are 25 years old who come from various types of companies such as government agencies, state-owned enterprises, private sector, and independent businesses.

The scale used in this study is the adaptation and trial of three scales that measure Psychological Capital, Job Crafting, and Work Engagement variables. To measure psychological capital variables, the scale used is the PsyCap Questioner (PCQ) with a reliability of 0.922 , this scale contains 24 items and was developed by Luthans et al. In 2007. Work engagement variables were measured by the Utrecht Work Engagement Scale (UWES) scale which had gone through a trial process and had reliability of 0.848 and consisted of 15 items. While for job crafting variables measured by Job Crafting Scale (JCS) which has also been on a trial process, this scale has 18 items and the reliability value is 0.775 (Andini, 2016).

\section{CONCEPTUAL FRAMEWORK}

Based on an empirical study, it was assumed that the effect of psychological capital on engagement with the job crafting as a mediator variable on generation $Y$ employess. The conceptual framework presented in Figure 1. 
Based on the conceptual framework above, the proposed research hypothesis is:

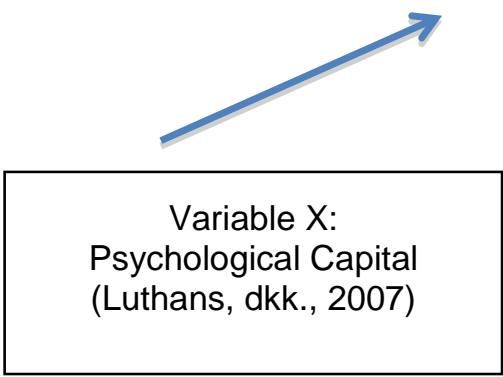

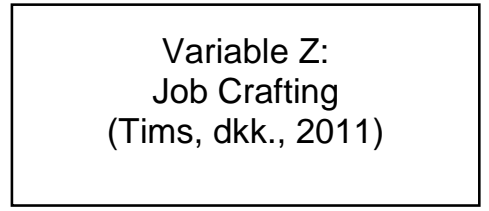

Job Crafting

(Tims, dkk., 2011)

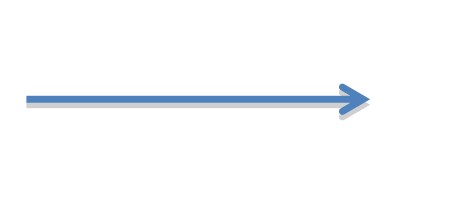

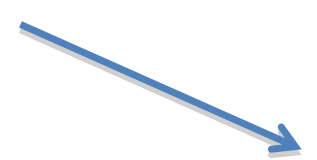

Variable Y:

Work Engagement

(Schaufeli,dkk., 2002)

Figure 1 - Conceptual Framework

Ha: There is effect of Psychological Capital on Work Engagement with Job Crafting as a mediator variable for $Y$ generation employees;

Ho: There is no effect of Psychological Capital on Work Engagement with Job Crafting as a mediator variable for $Y$ generation employees.

\section{RESULTS OF STUDY}

In this study, data analysis was performed using Baron and Kenny (1986) mediation test which stated that the procedure for analyzing mediator variables in a simple way can be done through a regression test. Before the regression test was carried out, the researcher conducted a correlation test on the three variables in this study. After that, researcher conducted a simple linear regression test and continued with multiple linear regression tests.

Table 1 - Correlation Statistics Results

\begin{tabular}{lllll}
\hline $\mathrm{n} / \mathrm{n}$ & Variable & 1 & 2 & 3 \\
\hline 1 & Psychological Capital & 1 & 0,668 & 0,682 \\
\hline 2 & Job Crafting & 0,668 & 1 & 0,556 \\
\hline 3 & Work Engagement & 0,682 & 0,556 & 1 \\
\hline
\end{tabular}

From the results of the correlation test above, the strength of the relationship between all variables is classified as moderate, where the relationship between the Psychological Capital variable and Job Crafting is 0.668 ; psychological capital with work engagement is 0.682 ; and the job crafting variable with work engagement is 0.556 . In this study, the three correlation results are significant because the significance value is less than 0.05 at the $5 \%$ significance level. It is seen that the direction of the relationship of all variables is positive. Thus, when the work engagement variable increases, the psychological capital and job crafting variables will also increase. Similar to psychological capital, when job crafting variables increase, psychological capital and work engagement variables will also increase.

Table 2 - Results of Regression Analysis

\begin{tabular}{lllllll}
\hline No & Regression Model & R Square & B Value & Beta & Significance & Description \\
\hline 1. & Regression X to $Y$ & 0,465 & 0,009 & 0,682 & 0,000 & Significant \\
\hline 2. & Regression X to Z & 0,447 & 0,359 & 0,668 & 0,000 & Significant \\
\hline \multirow{2}{*}{ 3. } & \multirow{2}{*}{ Regression X and Z to Y } & \multirow{2}{*}{0,483} & $0,007(\mathrm{X})$ & 0,561 & 0,000 & Significant \\
\end{tabular}

Baron and Kenny (1986) state that the effect of independent variable on dependent variable with the role of the mediator variable will be fulfilled if there are three conditions, such as: 1) estimating the estimated predictor value of the dependent variable regression ( $Y$ ) with an independent variable $(\mathrm{X})$ as a predictor, this is expected that the resulting value is 
significant; 2) 2) estimate the estimated predictor value of the mediator variable regression $(Z)$ with an independent variable $(X)$ as a predictor. At this stage it is expected that the resulting value is also significant; 3 ) Regress the dependent variable $(Y)$ with the independent variable $(X)$ and the mediator variable $(Z)$ as predictors. At this stage, the $Z$ prediction of $Y$ is expected to have a significant value.

From the table above, it can be seen that the results of the regression analysis are fulfilled in the first and second conditions with estimated predictors of 0.009 and 0.359 and the results obtained are significant. In the third condition, the mediator variable is proven to affect the dependent variable with the control of the independent variable. This is indicated by the insignificant results in the multiple regression model $\mathrm{x}$ with $\mathrm{y}$ with a significance level of 0,000 with an estimated predictor value of 0.007 and $z$ multiple regression to $y$ with a significance level of 0.100 with an estimated predictor value of 0.004 . The estimated value of the predictor $x$ against $y$ in the third equation of 0.009 is proven to be greater than the first equation. Therefore, the research hypothesis which states that there is a psychological capital effect on work engagement with job crafting as a mediator variable for $\mathrm{Y}$ generation employees is accepted and included in the type of perfect mediation.

\section{DISCUSSION OF RESULTS}

The purpose of this study was to determine the effect of psychological capital on work engagement through the role of job crafting in generation $Y$ employees. Based on the results of the regression analysis obtained in this study, it is known that job crafting can mediate the effect of psychological capital on work engagement. This is evidenced by the four requirements in the mediation test Baron and Kenny (1986) fulfilled.

The results of the analysis in the first equation state that psychological capital has an effect on work engagement can be categorized at a moderate level. This is in line with the research that conducted by Yassinia (2016) which states that psychological capital can affect work engagement by $55.3 \%$. In this study it was proven that psychological capital variables contribute to increasing one's work engagement. The results of previous studies conducted by Simons and Buitendach (2013) also state that employees who have psychological beliefs, expectations, and assessments of their work (eg. hope, optimism, resilience, and selfefficacy) can be seen as potential sources of positive emotions and attitudes and employee behaviour such as work engagement.

The results obtained in the second equation prove that psychological capital has an effect on job crafting. The previous research conducted by Cenciotti, et al. (2017) stated that psychological capital is a significant predictor of job crafting over time. On that research, psychological capital conceptualized as an aggregate of psychological resources similar to the COR (Conservation of Resource) concept. According to Hobfoll $(1989,1998)$, resources tend to appear and evolve in associate ways. Halbesleben, et al (2014; Hobfoll, 1988; Cenciotti, et al., 2017) stated that people with more resources are more likely to invest them in concrete actions to acquire new resources and achieve their goals than individuals with less resources. In accordance with these theoretical assumptions, their model revealed that an individual's initial level of personal resources (i.e., PsyCap) predicted their tendency to invest them in enacting proactive behaviours finalized at shaping their work environment (i.e., job crafting) (Cenciotti, et al., 2017).

In the third equation, it proves that the effect of psychological capital on work engagement will be slightly stronger if mediated by job crafting. Individuals with high psychological capital will tend to be more active in changing their work environment, for example undertaking new projects consistent with their beliefs of efficacy (Tims \& Bakker, 2010). Tims and Bakker also stated that the more successful employees are in using concrete behaviours to create better work conditions and develop their competencies. Vogt et al (2016; Cenciotti, et al., 2017) said that there is a positive and reciprocal longitudinal prediction of PsyCap by job crafting. This link suggests that the relation between resources (i.e., PsyCap) and investments (i.e., job crafting behaviours) is dynamic. Job crafting will increase psychological capital because employees can create positive working conditions in 
terms of learning opportunities, social support and challenging activities. Thus, generation $Y$ employees will feel more engaged to their work if they have a positive psychological state and are strengthened by their initiative in making changes related to job resources and demands in their work environment.

\section{CONCLUSION AND RECOMMENDATIONS}

Based on a series of analyzes conducted by researcher, it can be concluded that job crafting can mediate the effect of psychological capital on work engagement among generation $Y$ employees. Individuals who have a positive psychological state and initiative in making changes in their work environment will feel more engaged to their work. Thus, the alternative hypothesis $(\mathrm{Ha})$ in this study was accepted. In line with this, the results of research on Generation $\mathrm{Y}$ employees show a positive correlation between work engagement and psychological capital and job crafting.

From the results of this study, the authors propose several suggestions including: 1) the next researcher can conduct research related to other variables relating to generation $Y$ employees such as supervisory support, job enlargement, perceived organizational support and job enrichment; 2) related to the method, researchers can consider using external sources for data concerning psychological variables: for example, an employee's job crafting could be measured by asking supervisors for frequencies regarding their subordinates crafting behaviours; 3 ) researchers can measure psychological capital, job crafting, and work engagement from a multidimensional perspective.

\section{REFERENCES}

1. Andini, A.G. (2016). Pengaruh Job Crafting terhadap Keterikatan Kerja pada Generasi Y. Skripsi.

2. Cenciotti, et al. (2017). Psychological Capital and Career Success over Time: The Mediating Role of Job Crafting. Journal of Leadership and Organizational Studies. Vol 24(3). $372-384$.

3. Deloitte Consulting LLP. (2016). The 2016 Deloitte Millenial Survey, Winning over the next generation of leaders. Accessed on 14 Juli 2016 from https://www2.deloitte.com/content/dam/Deloitte/global/Documents/About-Deloitte/gxmillenial-survey-2016-exec-summary.pdf

4. Leiter, M. P., \& Bakker, A. B. (2010). Work Engagement: A Handbook of Essential Theory and Research. New York: Psychology Press.

5. Marais, M. H. (2013). "Retention and Engagement of Generation Y Engineers: A Hermeneutic Phenomenological Inquiry". Thesis. South Africa: Industrial and Organizational Psychology, University of South Africa.

6. Ozcelik, Gaye. (2015). Engagement and Retention of the Millenial Generation in the Workplace through Internal Branding. International Journal of Business and Management. Vol.10, No.3.

7. Park, J., \& Gursoy, D. (2012). Generation Effects on Work Engagement among U.S Hotel Employees. International Journal of Hospitality Management Vol.31, 1195-1202.

8. Rachmawati, Meida. (2013). Employee Engagement Sebagai Kunci Meningkatkan Kinerja Karyawan. International Journal Review. Vol.6. no.12.

9. Saks, M.A. (2006). Antecedent and Consequence of Employee Engagement. Journal of Managerial Psychology, 21(07), 600-619.

10. Schaufeli, W. B., Salanova, M ., Gonzales-Roma., V., \& Bakker, A. B.(2002). The Measurement of Engagement and Burnout: A Two Confirmatory Factor Analytic Approach. Journal of HappinesStudies, 71-92.

11. Schaufeli, W.B \& Bakker, A. B. (2003). Utrecht Work Engagement Scale. Occupational Health Psychology Unit. Utrecht University

12. Schullery, N. M. (2013). Workplace Engagement and Generational Differences in Values. Business Communication Quarterly Vol.76, No 2, 252-262. 
13. Tims, M., Bakker, A.B., \& Derks, D. (2011). Development and Validation of the Job Crafting Scale. Journal of Vocational Behaviour. 80, 173-186.

14. Wrzesniewski, Amy.,\& Dutton, J.E. (2001). Crafting a Job: Revisioning Employees as a Active Crafters of Their Work. Academy of Management Review. Vol 26, no 2, 179-201.

15. Halbesleben, J. R., \& Wheeler, A. R. (2008). The relative roles of engagement and embeddedness in predicting job performance and intention to leave. Work \& Stress, 22(3), 242-256.

16. KOMPAS. 14 Maret, 2016. "Korporasi Bersaing Mengikat Generasi Y". Koran KOMPAS, hal. 1

17. Luthans, F., Avolio, B. J., Avey, J. B., \& Norman, S. M. (2007). Positive psychological capital: Measurement and relationship with performance and satisfaction. Personnel psychology, 60(3), 541-572.

18. Yassinia, Sika. (2016). Pengaruh Modal Psikologis terhadap Keterikatan Kerja pada Relawan di Organisasi Gerakan Melukis Harapan. Skripsi.

19. Zemke, R., Raines, C., \& Filipczak, B. (2013). Generations at work: Managing the clash of boomers, gen Xers, and gen Yers in the workplace (2nd ed.). United States: AMACOM. 